\title{
El indudable beneficio de las Vacunas en la Pandemia COVID19
}

\author{
Sonia Arza Fernández ${ }^{1-2}$ \\ ${ }^{1}$ Universidad Nacional de Asunción, Facultad de Ciencias Médicas. \\ San Lorenzo, Paraguay \\ ${ }^{2}$ Ministerio de Salud Pública y Bienestar Social. Asunción, Paraguay
}

Para entender la importancia de una medida salubrista, es importante conocer y analizar el origen, el desarrollo y el impacto generado por dicha intervención. Al respecto, el ineludible valor de las vacunas, debe conciliarnos con la historia, para dimensionarlas acabadamente.

La literatura sostiene ${ }^{(1)}$ que el excelso momento de la inmunización no comenzó con la primera vacuna en 1796, cuando Edward Jenner demostró con la variolización, protección contra la viruela. Este origen está arraigado en las enfermedades infecciosas y se remonta a épocas tan lejanas como el año 1000 d.C., sustentado en los procesos de inoculación realizados en China e India. Durante 130 años, luego del descubrimiento de Jenner, iniciando con Louis Pasteur en 1885, su vacuna contra la rabia y luego en la década de 1930 con el desarrollo de antitoxinas, vacunas contra la difteria, el tétanos, el ántrax, el cólera, la peste, la fiebre tifoidea y la tuberculosis, se fortalecieron las esperanzas de erradicar enfermedades mediante inmunización.

Durante el siglo XX, la investigación y el cultivo viral en el laboratorio, dio como resultado la vacuna contra la poliomielitis, logrando secuencialmente, inmunobiológicos contra el sarampión, las paperas y la rubéola. Hoy, la línea del tiempo nos ubica en pleno siglo XXI, donde la ciencia unida a nuevas tecnologías, innovó el desarrollo de nuevas plataformas de vacunas como vector viral, ARNm y ADN recombinante, ampliando así los objetivos incluyendo a afecciones no infecciosas como la adicción y las alergias.

A finales de diciembre $2019^{(2)}$, la Provincia de Hubei, China nos actualizaba sobre una enfermedad respiratoria que generaba insuficiencia en muy breve tiempo. Los primeros días de enero 2020, identifican al nuevo Coronavirus, y su transmisión se expande, sin respetar espacio, condición ni tradición. Una nueva pandemia se instaló desde el 11 de marzo $2020^{(3)}$ y la búsqueda de una vacuna segura y eficaz que la detenga, congregó en una maratónica carrera a varios proyectos, de tres plataformas diferentes y esquemas de vacunación contra el COVID19.

Es justamente, en esta vorágine de innovaciones, donde el rigor de la pandemia, obligó distintos ensayos clínicos, durante el primer semestre 2020, iniciando el proceso de aprobaciones de vacunas contra COVID19, en varios países a noviembre del mismo año. Como muestra de eficacia y seguridad, la OMS aprobó secuencialmente el uso de emergencia de cuatro vacunas: plataforma ARNm de Pfizer/BioNTech (31 dic 2020), Vector Viral de AstraZeneca (15 febrero 2021), la de Johnson y Johnson (12 marzo 2021) y Moderna (1 mayo 2021). A finales de marzo 2021, avalaron la seguridad y la eficacia de las vacunas inactivadas chinas de los laboratorios Sinopharm y Sinovac, aguardando datos para promover su uso en emergencia. No obstante, a pesar de ser aprobadas por varios países, siguen enlistados, aguardando promoción por la OMS, las vacunas, Sputnik V (vector viral), y la de Cansino (vector viral). Mundialmente y a la fecha actual, se están administrando siete vacunas distintas de tres plataformas diferentes y la OMS agregará más aprobaciones en junio de este mismo año(4).

La inmunización es una de las intervenciones en salud pública más eficaces ${ }^{(5)}$. El Prof. Dr. Stanley Plotkin enunciaba que no existe una medida de más impacto en salud pública, después del agua potable, ni los antibióticos han logrado lo que las vacunas en el crecimiento y desarrollo de las poblaciones. Esta premisa encierra el impacto 
positivo de las mismas en el aminoramiento de la carga de las enfermedades a escala mundial. Sin descartar que, vacuna mediante, se ha logrado erradicar la viruela hace exactamente 40 años $^{(6)}$, mientras se avanzan pasos firmes para erradicar el virus polio ${ }^{(7)}$.

Recientemente, los distintos países del mundo iniciaban sus campañas de vacunación contra COVID19 ${ }^{(8)}$, y complacidos verificamos, como una nación en plena pandemia, merced a un ritmo acelerado de inmunización, cubriendo al $80 \%$ de su población, está reactivándose después de 1 año de limitaciones y encierros por cuarentenas. Israel primero y ahora Reino Unido se suman a este logro, siendo el reflejo incuestionable de las vacunas contra la enfermedad.

Si bien la inequidad de distribución de las vacunas contra COVID19 es un denominador común para los países en desarrollo, por ende, la disponibilidad escasa, no existe duda alguna del beneficio que proporcionan comparativamente al riesgo de adquirir la enfermedad. El mensaje inacabable que podemos ofrecer hoy, es que cualquier vacuna es mejor que ninguna, y que es indudable el gran beneficio que las mismas proporcionarán.

\section{REFERENCIAS BIBLIOGRÁFICAS}

1. Needham J, Lu G-D, Sivin N, Needham J. Science and Civilisation in China. 3. print. Cambridge: Cambridge Univ. Press; 2008. 261 p. (Science and civilisation in China Biology and biological technology; vol. 6).

2. Dong $E$, Du H, Gardner L. An interactive web-based dashboard to track COVID19 in real time. Lancet Infect Dis 2020; 20: $533-34$

3. Organización Panamericana de la Salud. OMS caracteriza COVID19 como Pandemia:

https://www.paho.org/es/noticias/11-32020-oms-caracteriza-covid-19-comopandemia

4. Organización Mundial de la Salud. Enfermedad por Coronavirus: Vacunas: https://www.who.int/es/news-room/qa-detail/coronavirus-disease-(covid19)-vaccines

5. Ministerio de Salud Pública y Bienestar Social. Normas Nacionales de
Sonia Arza Fernández Pediatra - Infectóloga Directora del PAI Periodo 2012-2018
Vacunación Técnico Administrativas y de Vigilancia del Programa Nacional de Enfermedades Inmunoprevenibles y PAI. Programa Nacional de Enfermedades Inmunoprevenibles y PAI. Ministerio de Salud Pública y Bienestar Social. Año 2017. ISBN 9789996736636

6. Kirby T. WHO celebrates 40 years since eradication of smallpox. Lancet Infect Dis. $2020 ; 20(2): 174$

7. Naciones Unidad. Noticias ONU (25 de agosto de 2020). «La OMS declara a África libre de poliomielitis»

8. Deutsche Welle. Governments and vaccination against COVID-19. doi: 10.1016/j.vacun.2021.03.001. https://www.dw.com/es/c\%C3\%B3mose-vive-la-nueva-normalidad-en-lospa\%C3\%ADses-1\%C3\%ADderes-envacunaci\%C3\%B3n/a-57339963

\section{The undoubted benefit of Vaccines in the COVID19 Pandemic}

To understand the importance of a health measure, it is important to know and analyze the origin, development and impact generated by the intervention. In this regard, the inescapable value of vaccines, must reconcile us with history, to fully dimension them.

The literature maintains ${ }^{(1)}$ that the lofty moment of immunization did not begin with the first vaccine in 1796, when Edward Jenner demonstrated protection against smallpox with variolization. This origin is rooted in infectious diseases and dates back as far back as 1000 AD, supported by the inoculation processes carried out in China and India. For 130 years, after Jenner's discovery, beginning with Louis Pasteur in 1885, his vaccine against rabies and then in the 1930s with the development of antitoxins, vaccines against diphtheria, tetanus, anthrax, 
cholera, plague, typhoid fever and tuberculosis, hopes of eradicating disease through immunization were strengthened.

During the twentieth century, research and viral culture in the laboratory, resulted in the vaccine against polio, achieving sequentially, immunobiological against measles, mumps and rubella. Today, the timeline places us in the 21st century, where science, together with new technologies, innovated the development of new vaccine platforms such as viral vector, mRNA and recombinant DNA, thus expanding the objectives to include non-infectious conditions such as addiction. and allergies.

At the end of December 2019(2), the Hubei Province, China updated us on a respiratory disease that generated insufficiency in a very short time. The first days of January 2020, they identify the new Coronavirus, and its transmission expands, without respecting space, condition or tradition. A new pandemic was installed since March $11,2020^{(3)}$ and the search for a safe and effective vaccine to stop it brought together several projects from three different platforms and vaccination schemes against COVID19 in a marathon race.

It is precisely in this vortex of innovations, where the rigor of the pandemic, forced different clinical trials, during the first semester of 2020, initiating the process of approvals of vaccines against COVID19, in several countries in November of the same year. As a demonstration of efficacy and safety, the WHO sequentially approved the emergency use of four vaccines: mRNA platform from Pfizer / BioNTech (Dec 31, 2020), Vector Viral from AstraZeneca (February 15, 2021) Johnson and Johnson (March 12, 2021) and (mRNA) Moderna (May 1, 2021). Then, at the end of March 2021, they endorsed the safety and efficacy of the inactivated Chinese vaccines from the Sinopharm and Sinovac laboratories, awaiting data to promote their use in emergency. However, despite being approved by several countries, the vaccines, Sputnik V (viral vector), and Cansino (viral vector) are still listed, awaiting promotion by the WHO. Globally and to date, seven different vaccines from three different platforms are being administered and the WHO will add more approvals in June of this year ${ }^{(4)}$.

Immunization is one of the most effective public health interventions ${ }^{(5)}$. Prof. Dr. Stanley Plotkin stated that there is no measure of greater impact on public health, after drinking water, nor have antibiotics achieved what vaccines have in the growth and development of populations. This premise contains their positive impact on reducing the burden of disease on a global scale. Without ruling out that, by means of vaccination, smallpox has been eradicated exactly 40 years ago ${ }^{(6)}$, while firm steps are being taken to eradicate the polio virus ${ }^{(7)}$.

Recently, the different countries of the world began their vaccination campaigns against COVID19 ${ }^{(8)}$, and we are pleased to verify, as a nation in the midst of a pandemic, thanks to an accelerated rate of immunization, covering $80 \%$ of its population, is reactivated after 1 year of limitations and lockdowns for quarantines. Israel first and now the United Kingdom join this achievement, being the unquestionable reflection of vaccines against the disease.

Although the inequity in the distribution of vaccines against COVID19 is a common denominator for developing countries, and therefore, the scarce availability, there is no doubt of the benefit they provide compared to the risk of acquiring the disease. The endless message that we can offer today is that any vaccine is better than none, and that there is no doubt the great benefit that they will provide. 